\title{
Habitat Characteristic and Reproductive Biology of the Flat-ribbed scallop, Decatopecten radula (Linnaeus, 1758) on the Coastal waters of Guiuan, Eastern Samar
}

\author{
Nonita S. Cabacaba ${ }^{1}{ }^{\star}$, Ed-Marie B. Boiser ${ }^{1}$, David N. Cosmiano Jr${ }^{2}$, Karen Patricia A. Fabile \\ ${ }^{1}$ National Fisheries Research and Development Institute Corporate 101 Building, Mother Ignacia Street, South Triangle, \\ Quezon City, 1103 Philippines - National Marinewater Research and Development Center, Sto. Niño, Guiuan, Eastern \\ Samar, ${ }^{2}$ Bureau of Fisheries and Aquatic Resources Region 8, Guiuan Marine Fisheries Development Center, Sto. Niño, \\ Guiuan, Eastern Samar, ${ }^{3}$ Environmental Bureau Region 8, DENR Compound, Jones St., Brgy. 2, Tacloban City, Leyte
}

\begin{abstract}
A B S T R A C T
Decatopecten radula is highly sought for its shell meat making it as a source of food and income for local shellfish gatherers in Guiuan, Eastern Samar. This study provides biological information for future conservation and management. Data were obtained monthly in the three selected sites within coastal waters of Guiuan, Eastern Samar from January 2016 to December 2016. These scallops were distributed at shallow areas of Trinidad Tubabao Island, Kamandag Reef, and Magluto Reef in depths of approximately 1-5 meters throughout the sampling period. Scallops are abundant in Kamandag reef where the site is characterized by its rocky area and mainly composed of a sandy bottom. Scallops were found on the surface of the sediment, attached to rocks or hard elements, hidden in a seagrass and seaweed. Physico-chemical parameters were observed within a narrow and normal range. Water temperature did not vary widely from $28^{\circ} \mathrm{C}$ to $30^{\circ} \mathrm{C}$ while salinity, $\mathrm{pH}$, and dissolved oxygen ranged from 33-34, 8.2-8.7, and 3.4-4.8 mg/L respectively. The results from the 825 scallops showed that $D$. radula is dioecious species with four gonad stages (developing, mature, spawning, spent) based on the histological examination and calculation of gonadosomatic index (GSI). The spawning period of the species is protracted and spawning peaks occur from August to November with a male-female sex ratio of 1:1.24. Size at sexual maturity reached $55 \mathrm{~mm}$ shell height (SH) in males and $60 \mathrm{~mm} \mathrm{SH}$ in females. Thus, the collection of scallop should be limited to individuals $>60 \mathrm{~mm}$ shell height.
\end{abstract}

*E-mail:nitz_sur@yahoo.com;nmfrdcguiuan@gmail.com

Received: 29 March 2017

Accepted: 14 December 2017
Keywords: habitat description, reproductive cycle, spawning peak, Gonadosomatic Index

\section{INTRODUCTION}

Scallops comprise a large family (Pectinidae) of 264 recognized species and are found globally in a wide range of marine habitats (Waller 1991). These bivalve mollusks have worldwide commercial significance. The consumption of seafood constitutes an important and essential part of the diet of many people in the world and the need for increased production will persist as the human population expands. In 2000, landings of bivalves from capture fisheries and aquaculture operations totaled 14,204,152 metric tons. From 1991 to 2000 there was a continuous increase in production of bivalves, and the landings more than doubled from 6.3 million tonnes in 1991 to 14 million tonnes in 2000 (Helm et al. 2004). Thus, extensive studies on the ecology and reproductive biology of many scallop species were done (Heald and Caputi 1981; Barber and Blake 1991; Brand 2006) to contribute to the biological information of these species that can be used for their conservation and management.

The flat-ribbed scallop Decatopecten radula (Linnaeus, 1758) is locally known as "saliray" in Guiuan,
Eastern Samar. It is commonly found on coarse sand and intertidal shallow sub-tidal waters to a depth of 20 meters (FAO 1998). Decatopecten radula is traded and collected mainly for its shell meat, making it as a source of food and income of local bivalve gatherers. Despite the contribution of scallop to the commercial fishery, there is limited information on the reproductive biology of this scallop species in the Philippines. Previous works have been done on the different scallop species. The study of the temperate Comptopallium radula in New Caledonia (Lefort and Clavier 1994) reported spawning of $C$. radula several times a month and the fluctuations of reproductive intensity are related to temperature and salinity fluctuations. Other previous works on the popular commercially important scallop, Amusium pleuronectes, were done by Del Norte et al. (1988) on its fishery in Lingayen Gulf and Gabral-Llana (1988) on growth, mortality, and recruitment in the Visayan sea. Recently, there have been reports on the related scallop species, Chlamys senatoria, by Morillo-Manalo et al. (2016) on the ecology and reproductive biology in Gigantes Islands, Carles, Central Philippines and exploitation of three 
related scallops Chlamys funebris, Chlamys senatoria, and Decatopecten nobilis by Soliman \& Dioneda (2004) in Asid Gulf, Masbate.

At present, there is no report on the reproductive biology of Decatopecten radula in Guiuan, Eastern Samar. This scallop species supports smallscale commercial fishery and is still poorly understood. Gaps in understanding this species would incline indiscriminate harvest that would result in the decline of its natural populations, making it vulnerable to depletion. Therefore, the main aim of this study was to describe the habitat, distribution and reproductive biology of flatribbed scallop along coastal waters of Guiuan, Eastern Samar. Results of this study would add to the baseline information which can be used in the management, conservation, and future aquaculture activities related to this species.

\section{MATERIALS AND METHODS}

\section{Sampling Area}

Guiuan, Eastern Samar is located $11^{\circ} 2^{\prime} 0^{\prime \prime} \mathrm{N}$ and $125^{\circ} 43^{\prime} 29^{\prime \prime} \mathrm{E}$ at the southern east most tip of the third largest island (Samar) in the Philippine archipelago, with a total surface area of $175.5 \mathrm{~km}^{2}$. Being located in the Pacific Ocean, Eastern Samar experiences great rainfall throughout the year. Magluto Reef, Kamandag Reef, and Trinidad Reef served as sampling sites for this study (Figure 1). The sampling sites are fringing reefs and located facing the Leyte Gulf. Magluto Reef is closest to the mainland. This reef is considered as one of the collection sites of several invertebrates like sea cucumber, spider conch, scallops, and other conch shells. Trinidad Reef is located in Tubabao Island, Guiuan Eastern Samar. The sampling area is located 60-70 meters from the shoreline of Brgy. Trinidad Tubabao Island. The main livelihood of the inhabitants are crab fishing and culturing high-valued fish in pens and corrals. The two sites are $4-4.8 \mathrm{~km}$ apart while Kamandag Reef is the farthest from the mainland among the sites.

\section{Habitat Characterization}

Through snorkeling, divers collected flat-ribbed scallops and physico-chemical parameters in the sampling area. Water parameters such as salinity, temperature, dissolved oxygen, depth, and $\mathrm{pH}$ were monitored monthly from January -December 2016 using Horiba Multiparameter Water Quality Checker. Sediment samples were collected only once throughout the sampling period. Using an improvised polyvinylchloride corer, sediment samples were collected to test organic matter content and were subjected to grain analysis following the method of Buchanan (1971). The collected sediment samples were brought straight to the National Fisheries Research and Development Institute, Guiuan Mariculture Research and Development Center (NFRDI-GMRDC). Samples were air dried and sent to the Philippine Rootcrops Laboratory at VSU, Baybay City, Leyte for sediment analysis. Sediment analysis was done based on the standard procedure of Walkley-Black (1986) with a revised version of Mylavarapu (2009). For water analysis, water samples were collected once to test the Phosphate $\left(\mathrm{PO}_{4}\right)$, Nitrate $\left(\mathrm{NO}_{3}\right)$, and Nitrite $\left(\mathrm{NO}_{2}\right)$ content of the seawater. The sea water samples were preserved using concentrated sulfuric acid $\left(\mathrm{H}_{2} \mathrm{SO}_{4}\right)$ and transported immediately to NFRDI laboratory, Quezon City for the analysis. Using the UV spectrophotometer, concentrations of Phosphate $\left(\mathrm{PO}_{4}\right)$, Nitrate $\left(\mathrm{NO}_{3}\right)$, and Nitrite $\left(\mathrm{NO}_{2}\right)$ were read and detected.

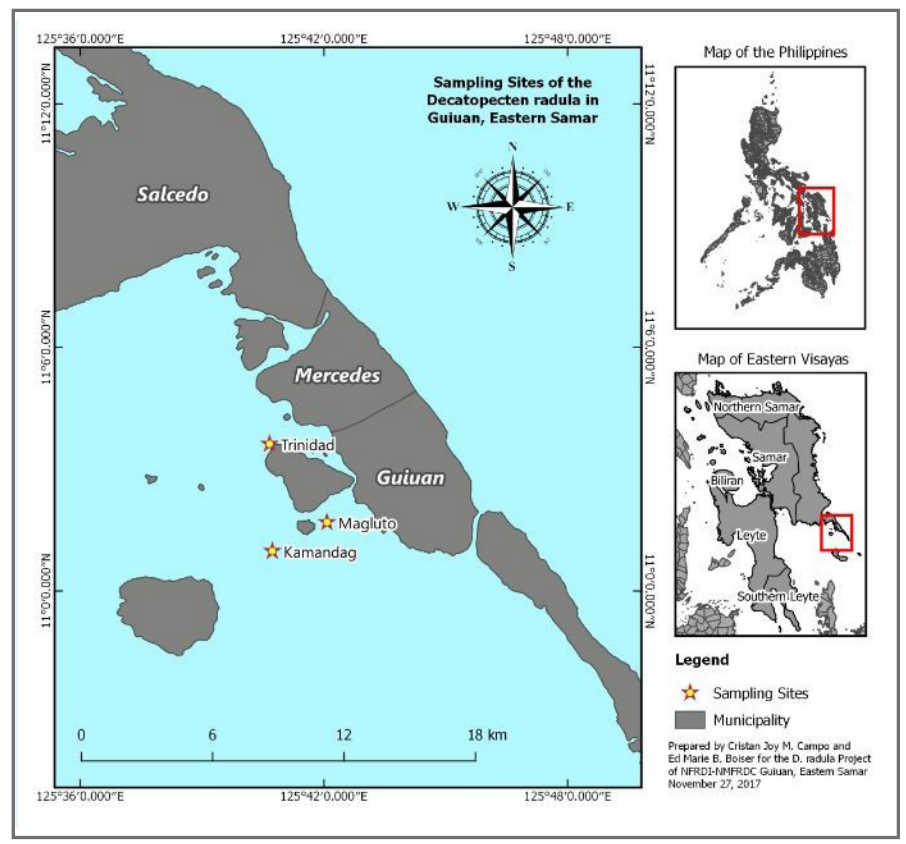

Figure 1. Sampling areas of the coastal areas of Guiuan, Eastern Samar at Trinidad Reef Tubabao Island, Kamandag Reef and Magluto Reef. 
Vegetation such as seagrasses or seaweeds in the selected sampling area were assessed. Seagrass assessment was conducted quarterly following the works done by English et al. (1994), Mckenzie et al. (2007), and Evans (2008). Within a selected area, three $100 \mathrm{~m}$ transect lines were laid out and positioned perpendicular to the shore. Transects were $25 \mathrm{~m}$ apart, parallel to each other and the start and end position of transects were recorded using GPS. Reading of seagrasses/seaweeds were taken by placing the $0.25 \mathrm{~m}^{2}$ quadrat from 0 meter to 100 meters with 10-meter interval. Each seagrass/seaweed species seen inside the quadrat were identified, recorded, and counted to determine the composition, abundance, and diversity of the sampling site using the methods of Saito and Atobe (1970) and English et al. (1994). Moreover, the percentage cover of seagrass and seaweed species in each quadrat were calculated using the following formula:

$$
\mathrm{C}=\frac{\sum \mathrm{Mix \textrm {fi }}}{f}
$$

where: $\mathrm{C}$ - cover

$\mathrm{Mi}$ - midpoint percentage of class i

$f$ - frequency (number of sectors with the same class of dominance i)

On the other hand, species abundance was determined by counting the individual seaweed or seagrass per species.

$$
\text { Density }=\frac{\text { Total number of individuals }}{\text { Total area }}
$$

\section{Scallop Sampling and Collection}

Monthly data collection and sampling was done from January 2016 to December 2016. Using the same transect from seagrass assessment, scallops found along transect were collected and counted to determine their density. Samples were analyzed in the laboratory straight from the collection. The specimens were scrubbed free of sand, mud, and attaching debris. The specimens were then weighed, measured, and dissected. The length of the shell, or the shell height, was measured from the dorsal hinge to the ventral margin of the shell and the shell width (SW)was measured from anteroposterior of the shell using a vernier caliper to the nearest $0.05 \mathrm{~mm}$. For the total weight of scallops, digital weighing scale to the nearest $0.01 \mathrm{~g}$ was used.

\section{Reproductive Cycle}

The relative frequencies of gonad stages were plotted against time to describe the reproductive cycle. The scallops were subjected to the identification of gonad stages through gonad histological analysis and gross morphology. The gonadosomatic index GSI was calculated using the formula base from Sastry (1963):

$$
\mathrm{GSI}=\frac{\text { Gonad weight }(\mathrm{g})}{\text { Gonad tissue weight }(\mathrm{g})} \times 100
$$

On the other hand, size at sexual maturity was determined by the scatter plot of the monthly gonadosomatic index (GSI) against shell height (SH).

\section{Histological Analysis}

Scallops were dissected and the gonad was removed carefully using the surgical scissors. Small, middle portion of the gonads was taken as a sample then preserved in $70 \%$ ethyl alcohol. Ethyl alcohol in this study was used because there is no available $10 \%$ seawater-formalin at Guiuan Center and the samples were needed to be preserved immediately. According to Nagorsen and Peterson (1980), for certain histological procedures, other fixatives may be desired because they penetrate tissues more rapidly than neutralized formalin and may render tissues more easily stained by certain histological dyes. In this study, 70\% alcohol was used as an alternative fixative agent which still gives clear and precise histological slides of the reproductive organs of scallops. Samples were sent and processed into slides to the Microtechnique Laboratory of the College of Fisheries and Ocean Sciences, UP Visayas, Miagao, Iloilo City. Using standard histological procedures (Humason 1972) the gonad samples were fixed in Bouin's solution. Through an alcohol series, samples were dehydrated before embedded in paraffin. Cross-sections (5- $\mu \mathrm{m})$ were stained with Hematoxylin and were counterstained with Eosin. The prepared slides were examined under a compound microscope and gonads were classified by sex and different stages of maturity. The morphological and histological description of the gonadal stages were made following available literature of development stages for other bivalves (Mason 1958; Hennick 1970; Llana and Aprieto 1980; Del Norte 1991; Nabuab and del NorteCampos 2006; Morillo-Manalo et al. 2016).

\section{Statistical Analysis}

Significance of sex ratio was calculated using Chi-square test to compare the male to female ratio to the expected 1:1 sex ratio. Statistical analyses were done using SPSS software.

\section{RES ULT S}

\section{Habitat Characterization}

Decatopecten radula was collected at shallow areas approximately 1-5 meters at the three sampling sites: Trinidad Tubabao Island, Kamandag Reef, and Magluto Reef. Trinidad Reef is characterized by its sand-mud substratum (particles $<63 \mu \mathrm{m}$ ) while Kamandag Reef and Magluto Reef are mainly composed of fine to coarse sand (particles $>63 \mu \mathrm{m}$ ) with coral rubbles and shell debris 
Table 1. Physico-chemical parameters of seawater in the sampling area in Guiuan, Eastern Samar from January 2016 to December 2016.

\begin{tabular}{lccc}
\hline \multicolumn{1}{c}{ Water Parameters } & Trinidad & Kamandag & Magluto \\
\hline $\mathrm{pH}$ & 8.4 & 8.5 & 8.5 \\
Dissolved oxygen $(\mathrm{mg} / \mathrm{L})$ & 3.5 & 4.1 & 4.3 \\
Temperature $\left({ }^{\circ} \mathrm{C}\right)$ & 29.2 & 29.2 & 30 \\
Salinity $(\mathrm{ppt})$ & 33 & 33 & 33 \\
\hline
\end{tabular}

Table 2. Seagrass/seaweed species composition and \% cover of the study sites in Trinidad Reef, Kamandag Reef, and Magluto Reef.

\begin{tabular}{lccc}
\hline \multicolumn{1}{c}{ Seagrass/ Seaweed Species } & Trinidad & Kamandag & Magluto \\
\cline { 2 - 4 } & \multicolumn{3}{c}{ Relative Density (\%) } \\
\hline Padina minor & 14.30 & 24.18 & 11.37 \\
Enhalus acoroides & 41.59 & 22.71 & 42.23 \\
Halodule univervis & 11.49 & 15.91 & 20.04 \\
Cymodocea serrulata & 0.58 & 13.55 & 18.20 \\
Syringodium isofi & 8.74 & 10.77 & 21.48 \\
Cymodocea rotundata & 10.98 & 4.63 & 5.89 \\
Halimeda opuntia & 10.19 & 16.38 & 22.07 \\
Halimeda mucronata & 8.54 & 7.52 & 25.96 \\
Thalassia hemprichii & 0.44 & 8.57 & 18.64 \\
Sargassum sp. & 14.20 & 22.62 & \\
Caulerpa rosea & 8.76 & 10.74 & \\
Laurencia papilosa & \multicolumn{3}{c}{1.49} \\
Total \% Cover & $\mathbf{6 6 . 7 4}$ & $\mathbf{5 9 . 1 7}$ \\
\hline
\end{tabular}

Seagrass and seaweed species and other commercially important fauna such as blue crab, spider conch, top shell, and giant clam were also observed. Seagrass species composition at Trinidad Reef and Magluto Reef is dominated by Enhalus acoriodes with a relative density of $41.59 \%$ and $42.23 \%$, respectively, while at Kamandag Reef, $24.18 \%$ relative density of Padina minor dominated the area (Table 2).The most diverse seagrass species composition was found at Kamandag Reef since most of the seagrass species identified were present in the area. The site with lesser seagrass composition was observed at Magluto Reef with only 9 identified species present. In terms of seagrass cover, each site ranges from $49-66.74 \%$ in which Trinidad Reef had the highest cover (66.74\%) followed by Kamandag Reef with $59.17 \%$ and the lowest cover was recorded in Magluto Reef with 49\%. Organic matter contents of sediments from all sampling sites were generally low ranging from $1.34 \%-1.6 \%$. Physicochemical parameters were observed within a narrow and normal range (Table 1$)$. Water temperature did not vary widely from 29 to $30^{\circ} \mathrm{C}$ while salinity, $\mathrm{pH}$, and dissolved oxygen ranged from $33,8.4-8.5$, and $3.5-4.3 \mathrm{mg} / \mathrm{L}$, respectively. Nitrate (NO3) and Nitrite (NO2) content of seawater showed relatively low results at all sampling sites. The concentration of nitrates had an average range of $0.2766-0.3756 \mu$-atoms $/ \mathrm{L}$ while nitrites had an average of $0.0370-0.0417 \mu \mathrm{g}$-atoms/L. For the phosphate analysis, the concentration was not detected using the UV spectrophotometer.

The scallop density along the sampling area of Kamandag Reef yielded the highest density of $49.41 \%$ compared to Magluto Reef (33.21\%) and Trinidad Reef
(18.39\%). Based on the scallop density, the flat-ribbed scallops were distributed and abundant in rocky areas like Kamandag Reef. This could be supported since Decatopecten radula, during sampling and collection, was found attached to rocks and other hard elements on the surface of the sediment. Occasionally, scallops were also found hidden in a seagrass/seaweed species (Appendix 1).

\section{Gonad Structure and Sex ratio}

The flat-ribbed scallop, Decatopecten radula, is a dioecious species where it is completely possible to differentiate male scallops from females by visual observation due to the difference in color. The color of male scallops ranged from whitish to creamy white while the females varies from pale yellow to creamy orange both depending on the degree of ripeness (Figure 2). No hermaphroditic scallops were observed throughout the study period. Gonad size also varied from flaccid to bulging as the scallops ripen.

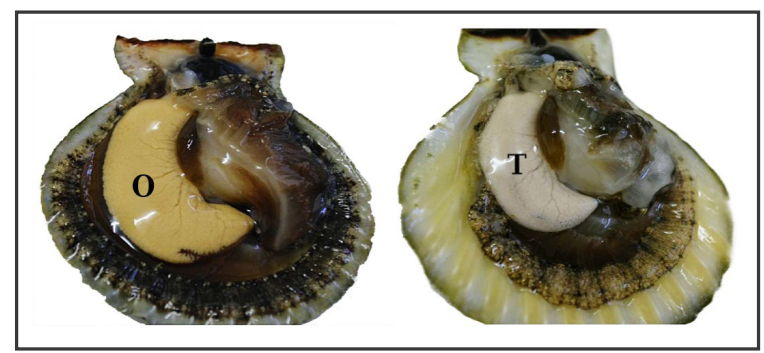

Figure 2. External morphology of female (left) and male (right) Decatopecten radula. $\mathrm{O}$ - ovary; $\mathrm{T}$ - testis. 
Table 3. Sex ratio of Decatopecten radula from January 2016 to December 2016.

\begin{tabular}{ccccc}
\hline Month & Male & Female & Total & Sex ratio (M:F) \\
\hline Jan-16 & 49 & 53 & 102 & $1: 0.92$ \\
Feb-16 & 35 & 21 & 56 & $1: 1.67$ \\
Mar-16 & 35 & 55 & 90 & $1: 0.64$ \\
Apr-16 & 46 & 46 & 92 & $1: 1.00$ \\
May-16 & 27 & 18 & 45 & $1: 1.50$ \\
Jun-16 & 15 & 26 & 41 & $1: 0.58$ \\
Jul-16 & 26 & 20 & 46 & $1: 1.30$ \\
Aug-16 & 38 & 64 & 102 & $1: 0.59$ \\
Sep-16 & 25 & 23 & 48 & $1: 1.09$ \\
Oct-16 & 30 & 63 & 93 & $1: 0.48$ \\
Nov-16 & 22 & 33 & 55 & $1: 0.67$ \\
Dec-16 & 20 & 35 & 55 & $1: 0.57$ \\
\hline TOTAL & $\mathbf{3 6 8}$ & $\mathbf{4 5 7}$ & $\mathbf{8 2 5}$ & $\mathbf{1 : 1 . 2 4}$ \\
\hline
\end{tabular}

A total of 825 flat-ribbed scallops with shell height $(\mathrm{SH})$ that ranged from $37-89 \mathrm{~mm}$ and $8.0-97.3 \mathrm{~g}$ total weight (TW) were collected from January 2016 to December 2016. These composed of $44.07 \%$ (368) males and $54.73 \%$ (457) females. Male to female ratio was 1:1.24 (Table 3). Scallops in the sampling sites are equally represented in the population. Chi-square test showed that there is no significant difference of the sex ratio (Chisquare $=0.993, \mathrm{P}<0.01)$.

\section{Gonad Stages}

The histological analysis of the gonads identified four distinct stages namely developing, mature, spawning, and spent. Occasional immature scallops were collected with shell height of 34 to $37 \mathrm{~mm}$ where gonad is undifferentiated as male or female since it was characterized by small, thin, and colorless gonad. The developing stage of scallops was visibly characterized by small and flattened gonad and the color ranges from pale/ transparent to creamy white for male and pale yellow to creamy orange for female. The follicles were small and occupied by dense area of spermatocytes while the female follicle had small and young developing oocytes. The mature stage had large, firm, bulging, and crescentshaped gonad while male follicles were packed with spermatozoa and female follicles were fully packed with spherical to polygonal mature oocytes. The spawning stage had a flaccid and thin gonad, follicles were thin, shrunk, and ruptured with loosely packed spermatozoa in males and loosely packed oocytes in females. The spent stage had reduced and shrunken gonad and the color ranges from pale to transparent for both male and female, follicles containing residual gametes, and some were empty. On the other hand, redeveloping stage was determined but in this study, it was considered under the spent stage. The redeveloping stage was characterized by similarly reduced and shrunken gonad and the color was from pale to transparent for both male and female. Follicles were observed containing residual gametes and some were empty except that the redeveloping stage had early gametogenic stages present at the periphery of the follicles. The macroscopic and microscopic descriptions of each stage were presented in Table 4 and were illustrated in Figure 3 for males and Figure 4 for females.

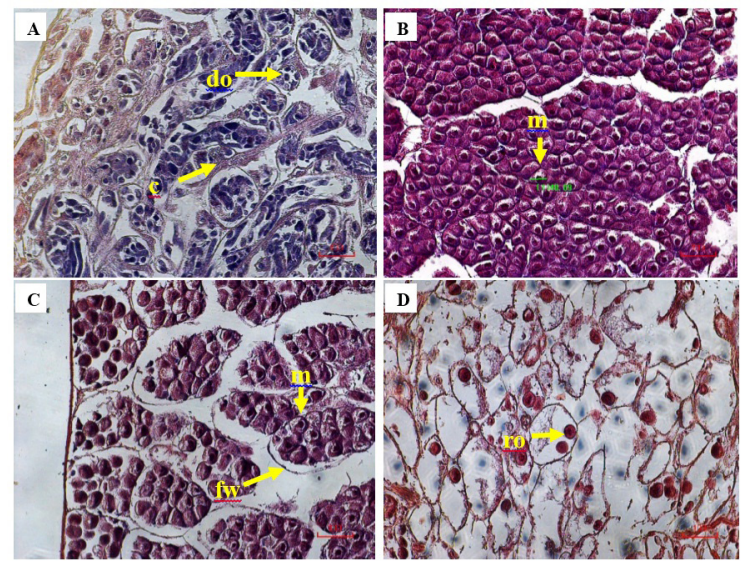

Figure 3. Microscopic description of female Decatopecten radula gonad stages: (A) developing; do - developing oocytes, ct - connective tissue; (B) mature; mo - mature oocytes; (C) spawning; mo - mature oocytes, fw - follicle wall; (D) spent; ro - residual oocytes. Scale bar $=100 \mu \mathrm{m}$.
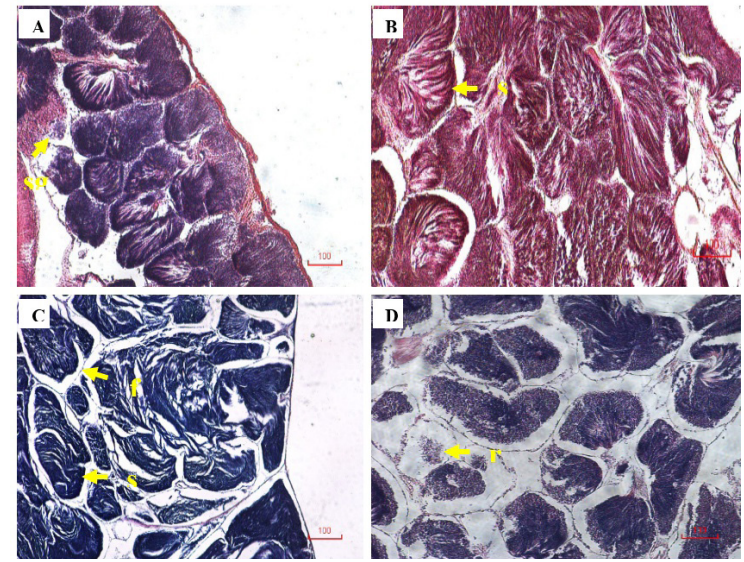

Figure 4. Microscopic description of female Decatopecten radula gonad stages: (A) developing; do - developing oocytes, ct - connective tissue; (B) mature; mo - mature oocytes; (C) spawning; mo - mature oocytes, fw - follicle wall; (D) spent; ro - residual oocytes. Scale bar $=100 \mu \mathrm{m}$ 
Table 4. Macroscopic and microscopic description of Decatopecten radula at different stages based from Nabuab and del Norte-Campos (2006) and Morillo-Manalo et al. (2016).

\begin{tabular}{|c|c|c|}
\hline Stage & Male & Female \\
\hline Developing & $\begin{array}{l}\text { The gonad is small and flattened. The texture } \\
\text { is smooth and fine and the digestive loop is } \\
\text { visible. The color ranges from pale/transparent } \\
\text { to creamy white. Follicles were small and } \\
\text { occupied by dense area of spermatocytes. }\end{array}$ & $\begin{array}{l}\text { The gonad is small and flattened. The texture is } \\
\text { smooth and fine and the digestive loop is visible. } \\
\text { The color ranges from pale yellow to creamy orange. } \\
\text { Follicles had small and young developing oocytes. } \\
\text { The connective tissue is present. }\end{array}$ \\
\hline Mature & $\begin{array}{l}\text { Large, firm, bulging, and crescent-shaped } \\
\text { gonad. The color is creamy white and the } \\
\text { texture is granular. The digestive loop is not } \\
\text { seen. Follicles were large and fully packed with } \\
\text { dense spermatozoa forming lines radiating to } \\
\text { the center of follicles. }\end{array}$ & $\begin{array}{l}\text { Large, firm, bulging and crescent-shaped gonad. } \\
\text { Color is pale yellow to creamy orange and the } \\
\text { texture is granular. The digestive loop is not seen. } \\
\text { Follicles were large and fully packed with spherical } \\
\text { to polygonal mature oocytes. }\end{array}$ \\
\hline Spawning & $\begin{array}{l}\text { Has a crescent-shaped flaccid gonad. The color } \\
\text { is creamy white and the texture is granular. The } \\
\text { digestive loop is visible. Follicles were thin, } \\
\text { shrunken, and ruptured with loosely packed } \\
\text { spermatozoa. Large spaces were present and } \\
\text { the gonad appeared streaky. }\end{array}$ & $\begin{array}{l}\text { Crescent-shaped flaccid gonad. The color is creamy } \\
\text { orange and the texture is granular. The digestive } \\
\text { loop is visible. Follicles were thin, shrunken, and } \\
\text { ruptured with loosely packed mature oocytes. } \\
\text { Large spaces were evident. }\end{array}$ \\
\hline Spent & $\begin{array}{l}\text { The gonad is greatly reduced in size and } \\
\text { shrunken. The color ranges from pale white } \\
\text { to transparent or colorless. The digestive } \\
\text { loop is clearly seen. Follicles have residual } \\
\text { spermatozoa. }\end{array}$ & $\begin{array}{l}\text { The gonad is greatly reduced in size and shrunken. } \\
\text { The color ranges from pale yellow to transparent or } \\
\text { colorless. The digestive loop is clearly seen. Follicles } \\
\text { are thin, shrunken, and contain residual oocytes } \\
\text { but some are empty. }\end{array}$ \\
\hline
\end{tabular}

\section{Reproductive cycle}

In this study, the reproductive cycle of Decatopecten radula was observed all throughout the sampling period (Figure 5). Pattern of spawning peaks were in August to November for both male and female wherein spawning males were $72.22 \%, 80.95 \%, 61.54 \%$ and $70.83 \%$ consecutively and for females with $65 \%$, $73.91 \%, 80.77 \%$ and $64.52 \%$ respectively. Relative frequency of developing scallops ranged from $4.54 \%$ to $62.96 \%$ for males and $2.5 \%$ to $21.73 \%$ for female. Mature scallops were observed monthly and higher values were observed in December and January. Spent scallops were occasionally observed and its relative frequency only ranged from $2.77 \%$ to $8.0 \%$.

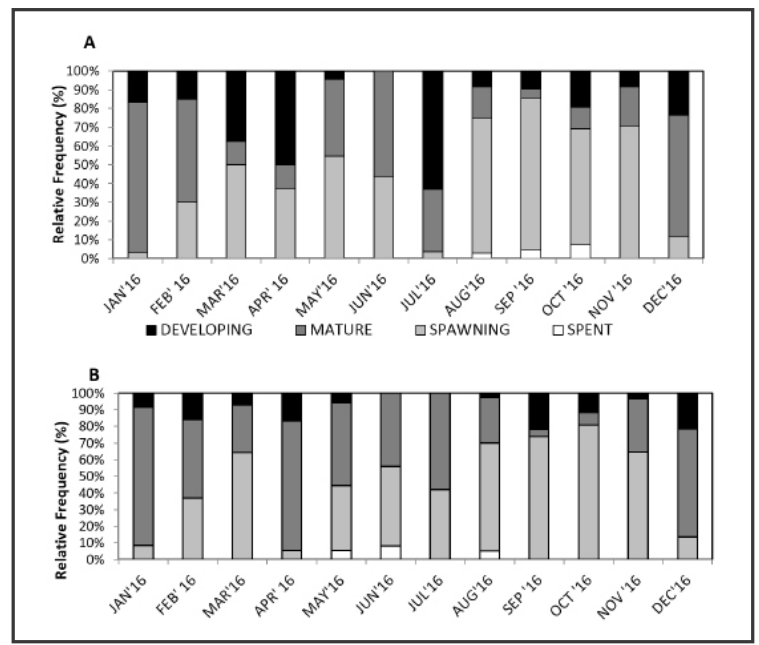

Figure 5. Gonad stages of male (A) and female (B) Decatopecten radula from January 2016 to December 2016.

\section{Gonadosomatic Index (GSI)}

Gonadosomatic Index (GSI) values ranged from $5.08-16.20 \%$ for male and $7.18-18.63 \%$ for female scallops. It was observed that females have slightly higher values than males (Figure 6). GSI is low when there is a high percentage of spawning scallops and GSI is high when there is also a high percentage of developing, mature scallops, usually prior to spawning period. The GSI values coincide with the observed spawning as a minor decrease of GSI values were observed in the month of March, then followed by a gradual increase until it reached a peak in the month of July then lower GSI values were observed again on August to November.

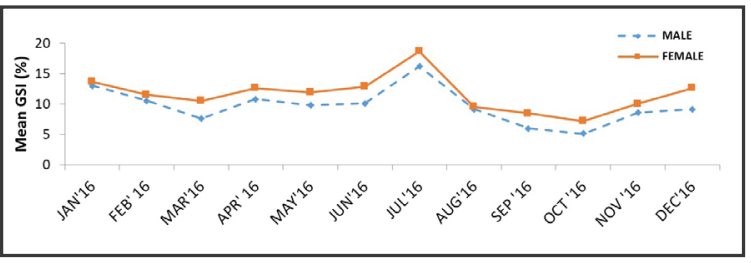

Figure 6. Gonadosomatoc index (GSI) of Decatopecten radula collected from January 2016 to December 2016.

\section{Size at sexual maturity}

The monthly scatter plot of gonadosomatic index (GSI) against shell height (SH) of female Decatopecten radula indicated gonad development wherein points cluster at around $60 \mathrm{~mm}$ therefore conservative estimate of $>60 \mathrm{~mm} \mathrm{SH}$ as minimum legal size was established. 


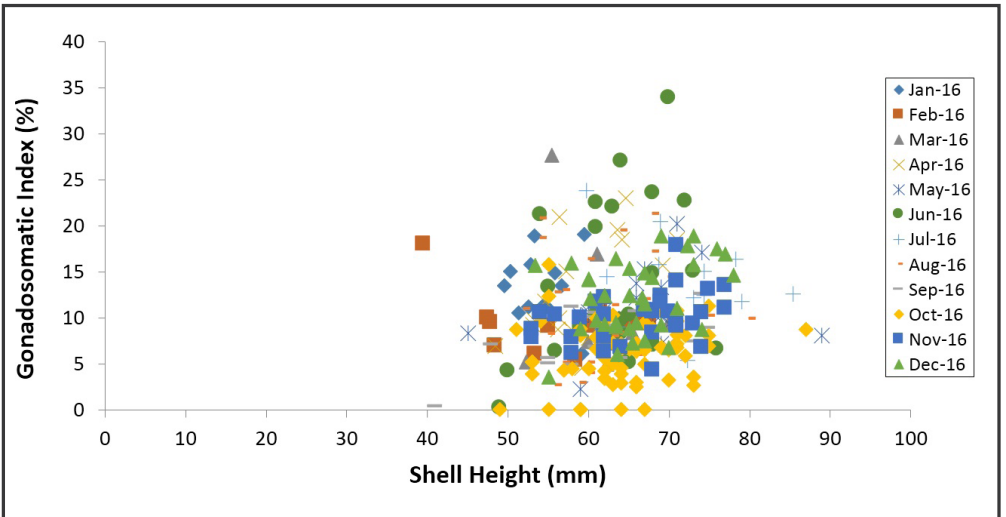

Figure 7. Scatter plot of gonadosomatic index (GSI) against shell height $(\mathrm{mm})$ of female Decatopecten radula. $\mathrm{n}=825$ individuals. Arrow is conservative estimate of lenght at massive sexual maturity.

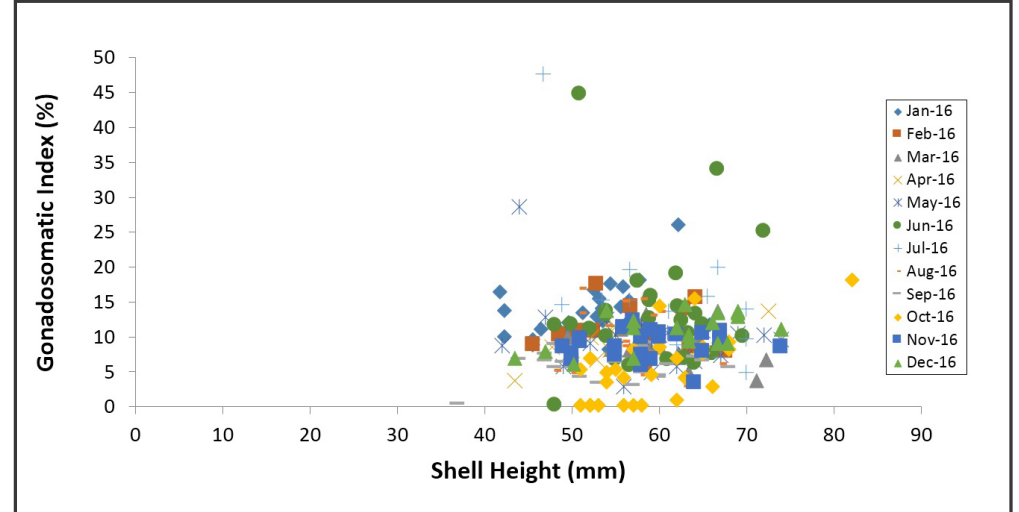

Figure 8. Scatter plot of gonadosomatic index (GSI) against shell height ( $\mathrm{mm}$ ) of male Decatopecten radula. $\mathrm{n}=825$ individuals. Arrow is conservative estimate of length at massive sexual maturity.

(Figure 7). For male Decatopecten radula, gonadal development started at around $55 \mathrm{~mm}$ and minimum legal size was estimated at $>55 \mathrm{~mm} \mathrm{SH}$ (Figure 8 ).

\section{D I S C U S S I O N}

The result of this study showed that Decatopecten radula occurs in rocky areas with sandy bottoms at the depth of 5 meters. Scallops were abundant and distributed at Kamandag Reef where the site is characterized by its rocky area. Patches of seagrass and seaweed species were present and most of the scallops were found on the surface of the sediment, attached to rocks or hard elements, hidden in a seagrass and seaweed (Appendix 1). According to Brand (2006), scallops are widely distributed in shallow intertidal waters to a depth of 7,000 $\mathrm{m}$ and the substrate range from mud, sand, pebbles, rocks, and boulders (Caddy 1989). The previous studies in the Philippines on the scallops Chlamys funebris, Chlamys senatoria nobilis, and Decatopecten striatus in the Gulf of Masbate also reported that these species were present in rocky areas and sandy bottoms at 23-40 m (Soliman and Dioneda 2004). Another study on the common Asian moon scallop Amusium pleuronectes in Lingayen Gulf and the Visayan Sea appears in sandy-mud to muddy bottoms at 12-40 m (Del Norte et al. 1988; Gabral-Llana 1988).
The macroscopic and microscopic examination of the flat-ribbed scallop, Decatopecten radula, showed that this species is dioecious. The reproductive system of the Pectinidae is unique because some members are hermaphrodites while others are dioecious (MorilloManalo et al. 2016). Scallops that are hermaphrodites include Amusium pleuronectes (Llana and Aprieto 1980; Del Norte 1988), Pecten maximus (Mason 1958), and Agropecten ventricosus (Luna-González et al. 2000), whereas dioecious scallop species include Pecten tenicostata (Rees 1957) and Placopecten magallanicus (Naidu 1970). The male to female ratio is $1: 1.24$ with no significant difference from the expected 1:1 sex ratio. This implies that scallops in the sampling sites are equally represented in the population to ensure a sustainable breeding.

Being in the tropics, the reproductive activity of Decatopecten radula is continuous with no sharp seasonal trends (Sastry 1979), unlike in temperate areas where the scallops exhibit a seasonal pattern (Giguere et al. 1994; Dibacco et al. 1995). The spawning of Decatopecten radula was observed throughout the year. This was supported by the co-occurrence of spawning and mature gonad stages in all sampling months. Therefore, $D$. radula showed protracted or continuous reproductive cycle. According to Bigatti et al. (2001) maintaining ripe oocytes allows 
The Philippine Journal of Fisheries 25 (1): 107-117

scallop to spawn whenever environmental conditions become favorable for larval survival and development. Geiger et al. (2010) stated that a prolonged spawning period in scallops favors a greater reproductive output. The observed spawning of Decatopecten radula from August to November is not similar to the Amusium peuronectes that spawns throughout the year, with one major peak in January or February and one minor peak between June and October or July and September (Llana and Aprieto 1980; Del Norte 1991). According to Naidu (1970), fluctuation in water temperature, either an increase or a decrease, is considered to be the most important factor in the initiation of spawning. Major spawning peaks of Decatopecten radula were associated with an increase in temperature, around $29-30^{\circ} \mathrm{C}$ during the months of Aug-Nov while minor spawning peaks were observed from January to March with temperature ranging from $28-29^{\circ} \mathrm{C}$. There have been published studies that reported various spawning associated with an increase and decrease in temperature. Species of scallops associated with an increase in temperature includes Chlamys opercularis (Ursin 1956), Chlamys islandica (Thorarinsdottir 1993), Amusium balloti (Heald and Caputi 1981), and Patinopecten yessoensis (Kawamata 1983), while spawning associated with a decrease in temperature includes Argopecten irradians concentricus (Sastry 1963; Barber and Blake 1983), Argopecten irradians irradians (Tettelbach et al. 1999), and Argopecten gibbus (Miller et al.1981). The Gonadosomatic Index (GSI) values also support the observation of synchronized spawning for male and female $D$. radula throughout the study period. The synchronized release of gametes was done to maximize successful fertilization and larval production (Morillo-Manolo et al. 2016).

Gonadosomatic Index (GSI) values ranged from $5.08-16.20 \%$ for male and $7.18-18.63 \%$ for female scallops. According to Barber \& Blake (1991, 2006) variations in gonad weight or GSI over time represent the progress of reproduction where increasing values indicate gametogenesis whereas decreasing ones indicate spawning and the energetic cost is believed to be higher in females than in males, given the large size of the egg relative to the sperm.

Like most invertebrates, scallops must reach a certain minimum age or size before gametogenesis is initiated (Barber and Blake 2006). The age or size at sexual maturity in Pectinidae varies between species. For Argopecten gibbus (Miller et al. 1981) size ranged from 71 days or $20 \mathrm{~mm}$ and Chlamys islandica (Wiborg 1963 ) with $35-40 \mathrm{~mm}$. The size at first sexual maturity of Decatopecten radula was attained at $60 \mathrm{~mm}$ for females and $55 \mathrm{~mm}$ for males which implies that males mature earlier than females. The scallops Chlamys funebris, Chlamys senatoria nobilis, and Decatopecten striatus reach sexual maturity at $61.3 \mathrm{~mm}, 58.9 \mathrm{~mm}$, and 60.1 $\mathrm{mm}$, respectively (Soliman and Dioneda 2004), whereas Amusium pleuronectes is sexually matured at $54-54.5 \mathrm{~mm}$ (Llana and Aprieto 1980; Del Norte 1991).

\section{C O N C L US I O N}

Therefore, the present result of this study suggests that for future conservation and management of Decatopecten radula, the collection of individuals should be regulated during the spawning peak months of August to November. The size should be limited to those with shell height $>60 \mathrm{~mm}$. This information will contribute to the collection of matured broodstocks from the wild and the schedule for the spawning activities in the hatchery can now be known. Moreover, sustainability of this resource can be ensured through a better understanding of some aspects of its reproduction.

\section{ACKNOWLED GMENT}

The authors are thankful for the support and effort of Guiuan Marine Fisheries Development Center (GMFDC) and Guiuan Marine Research Development Center (GMRDC) staff during the collection and monthly sampling. Also, we would like to thank those who review this paper and contribute valuable comments and suggestions.

\section{R E F E R E N C E S}

Barber BJ, Blake NJ. 1983. Growth and reproduction of the bay scallop Argopecten irradians (Lamarck) at its southern distributional limit. J. Exp. Mar. Biol. Ecol. $66: 247-256$.

Barber BJ, Blake NJ. 1991. Reproductive physiology. In: Shumway, S. E., editor. Scallops: biology, ecology and aquaculture. Amsterdam, The Netherlands: Elsevier. pp. 377-428.

Barber BJ, Blake NJ. 2006. Reproductive physiology. In: Shumway, S. E. \& G. J. Parsons, editors. Scallops: biology, ecology and aquaculture. Amsterdam, The Netherlands: Elsevier. pp. 357-416.

Bigatti G, Penchaszadeh PE, Mercuri G. 2001. Aspects of the gonadal cycle in the Antarctic bivalve Laternula eliptica. J. Shellfish Res. 20:283-287.

Brand AR. 2006. Scallop ecology: distributions and behavior. In: Shumway, S. E. \& G. J. Parsons, editors Scallops: biology, ecology and aquaculture. Amsterdam, The Netherlands: Elsevier. pp. 651744.

Buchanan JB. 1971. Measurements of the physical and chemical environment. In: Holme, N. \& A. D. McIntyre, editors. Methods for the study of marine benthos. IBP Handbook 16. Oxford, United Kingdom: Blackwell Scientific Publication. pp. 3058. 
Caddy JF. 1989. A perspective on the population dynamics and assessment of scallop fisheries, with special reference to the sea scallop, Placopecten magellanicus (Gmelin). In: Caddy, J. F., editor. Marine invertebrate fisheries: their assessment and management. New York, NY: John Wiley \& Sons. pp. $559-589$.

Del Norte AGC. 1991. Aspects of the growth, recruitment, mortality and reproduction of the scallop Amusium pleuronectes (Linne) in the Lingayen Gulf, Philippines. Ophelia 29:153-168.

Del Norte AGC, Capuli, EC. 1988. The scallop fishery of Lingayen Gulf, Philippines. Asian Fish. Sci. 1:207213.

FAO. 1998. FAO Species identification guide for fishery purposes. The living marine resources of the Western Central Pacific: Volume 1. Seaweeds, coarals, bivalves and gastropods. In: Carpenter KE, VH Niem (eds). Rome, FAO. 686 pp.

Gabral-Llana ME. 1988. Growth, mortality and recruitment of the Asian moon scallop (Amusium pleuronectes) in the Visayan Sea, Philippines. In: Venema, S., J. Moller-Christensen \& D. Pauly, editors. Contributions to tropical fisheries biology: papers by the participants of FAO/DANIDA followup training courses. FAO Fisheries Report 389. Rome, Italy: FAO. pp. 16-24.

Geiger SP, Stephenson SP, Arnold WS. 2010. Protracted recruitment in the bay scallop Argopecten irradians in a west Florida estuary. J. Shellfish Res. 29:809817. Giese, A. C. \& J. S. Pearse. 1974. Introduction: general principles. In: Giese, A. C. \& J. S. Pearse, editors. Reproduction of marine invertebrates. 1:149. New York, NY: Academic Press. 546 pp.

Giguere M, Cliche G, Brulotte S. 1994. Reproductive cycle of the sea scallop Placopecten magellanicus (Gmelin) and the iceland scallop Chlamys islandica (O.F. Muller) in Iles de la Madeleine, Canada. Journal of Shellfish Research 13(1): 31-36.

Heald DI, Caputi N. 1981. Some aspects of growth, recruitment and reproduction in the southern saucer scallop, Amusium balloti (Bernardi, 1861) in Shark Bay, Western Australia. Fish. Res. Bull. 25:133.

Helm MM, Bourne N, Lovatelli, A. 2004. (comp./ed.) Hatchery culture of bivalves. A practical manual. FAO Fisheries Technical Paper. No. 471. Rome, FAO. 2004. 177p

Hennick DP. 1970. Reproductive cycle, size at maturity and sexual composition of commercially harvested weathervane scallop (Patinopecten caurinus) in
Alaska. J. Fish. Res. Board Can. 27:2112-2119. Humason, G. L. 1972. Animal tissue techniques. San Francisco, CA: W. H. Freeman \& Co. 725 pp.

Humason GL. 1972. Animal tissue techniques. San Francisco, CA: W. H. Freeman \& Co. 725 pp.

Kawamata K. 1983. Reproductive cycle of the scallop Patinopecten yessoensis (Jay), planted in Funka Bay, Hokkaido. Sci. Rep. Hokkaido Fish. Exp. Stn. 25:1520 .

Lefort Y, Clavier J. Reproduction of Anmchlamys flabellata, Comptopallium radula and Mimachlamys gloriosa (Mollusca: Pectinidae) in the south-west lagoon of New Caledonia Aquat. Living Resour.,1994, 7, 3946.

Llana ME, Aprieto VL. 1980. Reproductive biology of the Asian moon scallop Amusium pleuronectes. Fish. Res. J. Philipp. 5:1-10.

Luna-Gonzalez A, Caceres-Martınez C, Zu nigaPacheco C, Lopez-Lopez S, Ceballos-Vasquez BP. 2000. Reproductive cycle of Argopecten ventricosus (Sowerby, 1842) in the Rada del Puerto de Pichilingue, B. C. S. Mexico and its relation to temperature, salinity and food. J. Shellfish Res. 19:107-112.

Mason J. 1958. The breeding of the scallop, Pecten maximus (L.) in Manx waters. J. Mar. Biol. Ass. U.K. 37:653-671.

Miller GC, Allen DM, Costello TJ. 1981. Spawning of the calico scallop Argopecten gibbus in relation to season and temperature. J. Shellfish Res. 1:17-21.

McKenzie LJ, Campbell SJ, Vidler KE, Mellors JE. 2007. Seagrass-watch:manual for mapping and monitoring seagrass resources. (Seagrass-watch HQ, Caims) 114 p (www.seagrasswatch.org/manuals.html).

Morillo-Manalo L, Quinitio GF, Laureta LV, Anasco NC, Montecarlo HM. 2016. Ecology and Reproductive Biology of the Senatorial Scallop Chlamys senatoria (Gmelin, 1971) in Gigantes Islands, Carles, Central Philippines. Journal of Shellfish Research. Vol. 35, No. 1, 17-25.

Naidu KS. 1970. Reproduction and breeding cycle of the giant scallop Placopecten magellanicus (Gmelin) in Port au Port Bay, Newfoundland. Can. J. Zool. 48:1003-1012.

Rees WJ. 1957. The living scallop. In: Cox, I., editor. The scallop: studies of a shell and its influence on human kind. London, United Kingdom: Shell Transport \& Trading Co., Ltd. pp. 15-32. 
Sastry AN. 1963. Reproduction of the bay scallop Aequipecten irradians Lamarck. Influence of temperature on maturation and spawning. Biol. Bull. (Woods Hole) 125:146-153.

Sastry AN. 1979. Pelecypoda (excluding Ostreidae). In: Giese, A. C. \& J. S. Pearse, editors. Reproduction of marine invertebrates. New York, NY: Academic Press. pp. 113-292.

Soliman VS, Dioneda RR. 2004. Quick stock assessment of the commercial scallops (Bivalvia: Pectinidae) in Asid Gulf, Masbate. UPV J. Nat Sci. 9:165-176.

Tettelbach ST, Smith CF, Smolowitz R, Tetrault K, Dumais S. 1999. Evidence for fall spawning of northern bay scallops Argopecten irradians irradians (Lamarck, 1819) in New York. J. Shellfish Res. 18:47-58.
Thorarinsdottir GG. 1993. The Iceland scallop, Chlamys islandica (O. F. Muller) in Breidafjordur West Iceland II. Gamete development and spawning. Aquaculture 110:87- 96.

Ursin E. 1956. Distribution and growth of the queen Chlamys opercularis (Lamellibranchiata) in Danish and Faroese waters. Medd. Dan. Fisk. Havunders. 1:1-32.

Waller TR. 1991. Evolutionary relationships among commercial scallops (Mollusca: Bivalvia: Pectinidae). In Shumway SE (ed), Scallops: Biology, ecology and aquaculture. New York: Elsevier, 73 pp

Wiborg KF. 1963. Some observations on the Iceland scallop, Chlamys islandica (Muller), in Norwegian waters. Fiskeridir. Skr. (Havunders.) 13:38-53 (Havunders) 

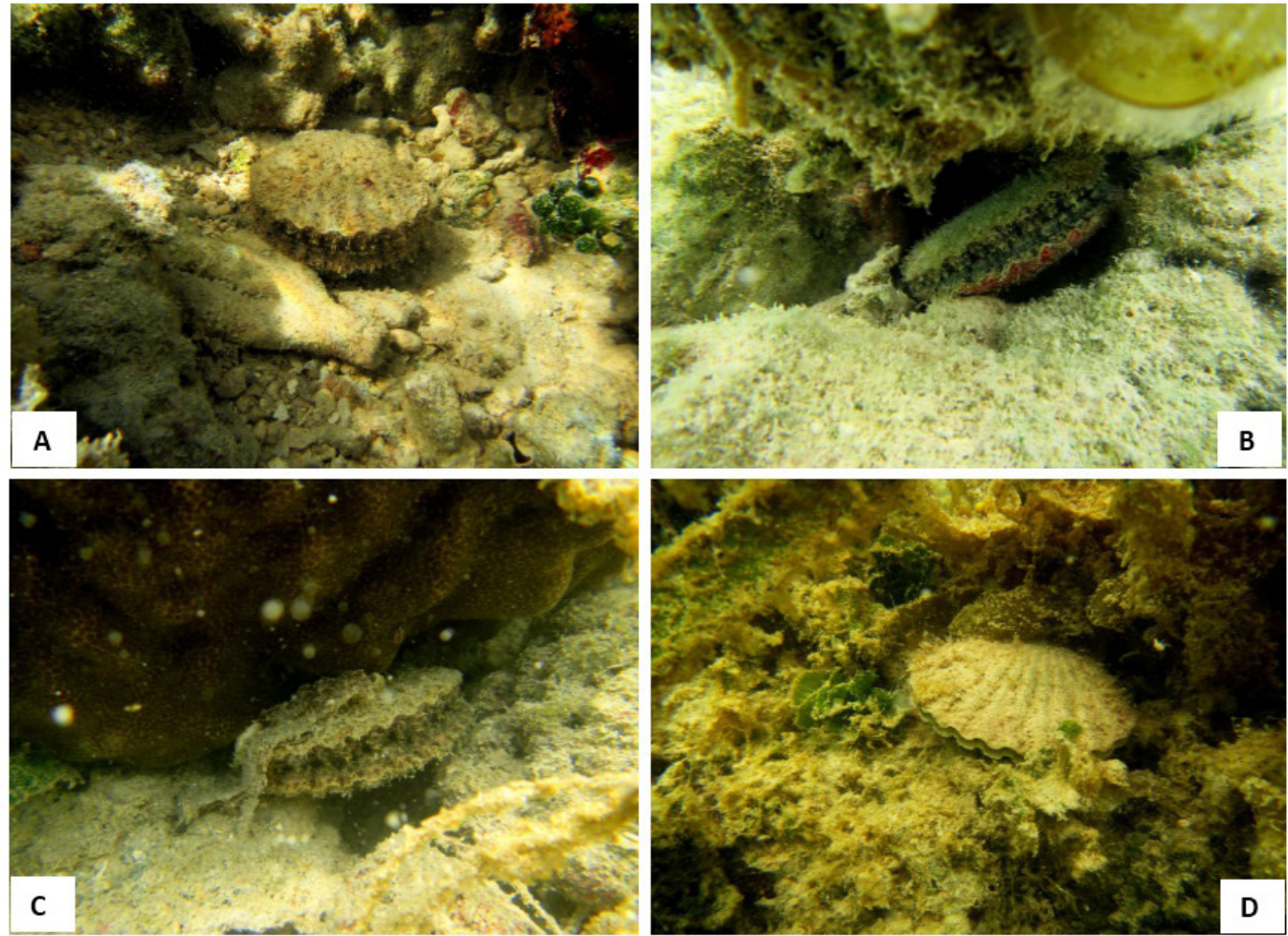

Appendix 1. Underwater photographed of Decatopecten radula found at A.) on the surface of the sediment, B.) between rocks, C.) attached to corals and D.) hidden under seagrasses/seaweed species at Trinidad Reef, Kamandag Reef and Magluto Reef.
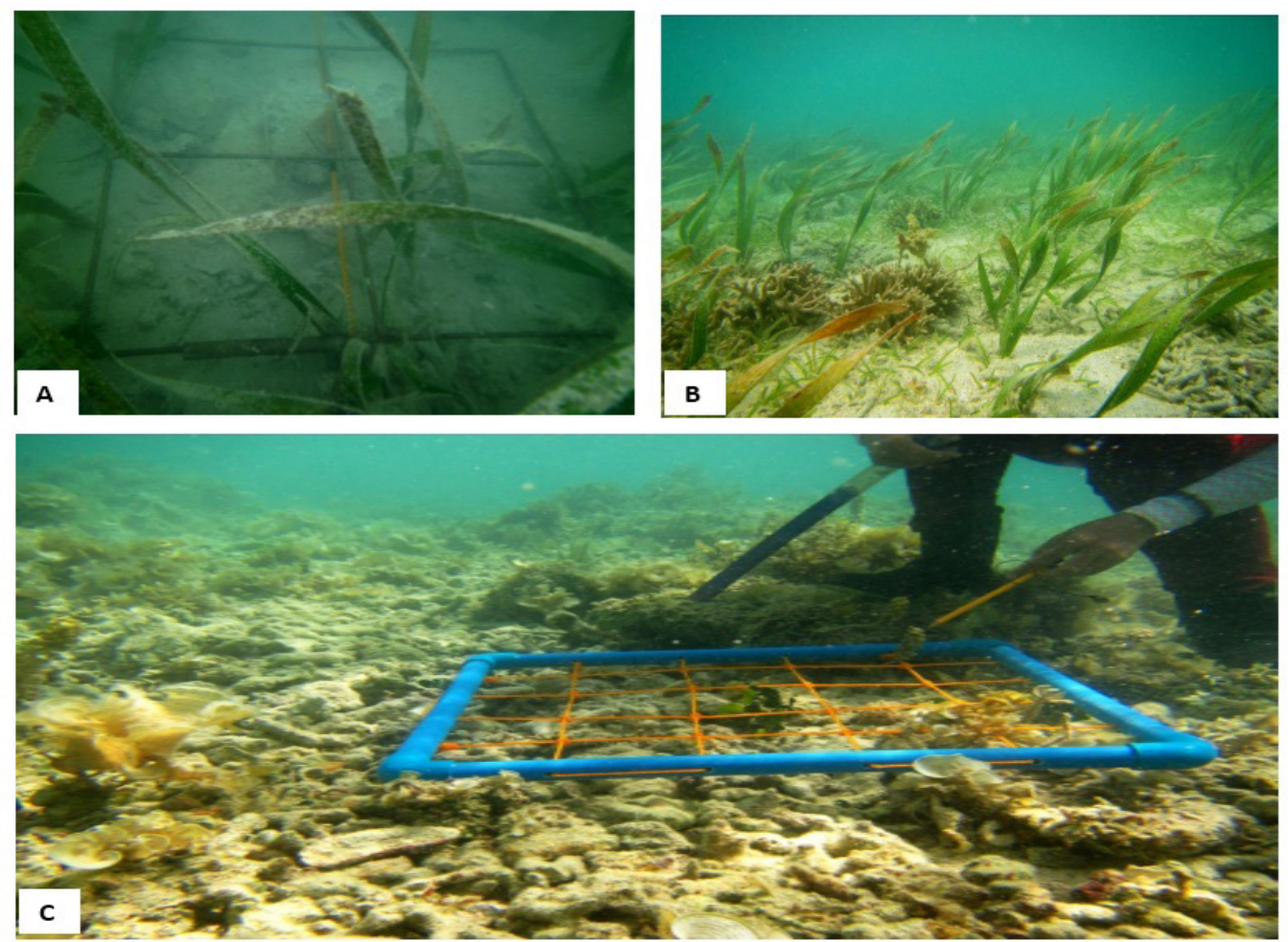

Appendix 2. Underwater photographed of sea beds from the sampling sites of A.) Trinidad Reef (seagrass species Enhalus acoroides and sand-mud substrate) B.) Magluto Reef (seagrass species Enhalus acoroides and fine sandy substrate) and C.) Kamandag Reef (rocky substratum with coral rubbles and shell debris) in Guiuan, Eastern Samar. 